\title{
Prospeksi Kawasan Pindul Sebagai Kampus Lapangan Hidrologi dan Geomorfologi Karst
}

\author{
Galih Dwi Jayanto, Slamet Suprayogi, Setyawan Purnama dan \\ Ahmad Cahyadi \\ Departemen Geografi Lingkungan, Fakultas Geografi, Universitas Gadjah Mada \\ Yogyakarta
}

\section{Intisari}

Keunikan kawasan karst Goa Pindul mendorong pemanfaatan yang maksimal dengan tetap menjaga asas kelestarian. Beberapa usaha yang dapat dilakukan adalah dengan menjadikan kawasan ini untuk menjadi kampus lapangan khususnya bagi studi hidrologi dan geomorfologi karst. Penelitian ini bertujuan untuk mengetahui prospek pengembangan kampus lapangan di kawasan Goa Pindul, Kecamatan Karangmojo, Kabupaten Gunungkidul. Inventarisasi data objek yang dapat digunakan sebagai situs amatan dilakukan di kawasan ini dengan menganalisis potensi pengembangan dengan menggunakan metode SWOT. Hasil analisis berupa deskripsi dan peta sebaran lokasi disajikan dalam paper ini.

Kata Kunci: Goa Pindul, Karst, Prospeksi, Kampus Lapangan

\section{Pendahuluan}

Indonesia memiliki bentuklahan karst yang bervariasi yang dapat ditemukan hampir di seluruh pulau dan kepulauan di Indonesia. Istilah karst secara terminologi berasal dari kata "Kras" yang berasal dari Bahasa Jerman dan diadopsi dari Bahasa Slovenia Sweeting (1972). Awalnya kawasan karst lebih dikenal sebagai lahan yang gersang dan berbatu. Hal ini tidak lepas dari karakteristik hidrologinya yang menyebabkan kondisi kering di bagian permukaan dan kondisi basah di bagian bawah permukaan (berupa sungai bawah tanah) (Cahyadi, 2010; Cahyadi, 2014).

Secara geomorfologi karst merupakan bentuklahan hasil proses pelarutan yang terjadi pada batuan mudah larut yang umumnya batuan karbonat oleh air (Cahyadi dkk., 2013a). Gilli (2015) menyebutkan bahwa bentukan-bentukan yang dapat ditemui di bentangalam karst sangat bervariasi, akan tetapi karakteristik komponen karst secara umum ada 5 hal yakni adanya karren atau lapies, adanya cekungan tertutup atau doline, ditemukan adanya goa dan sistem pergoaan, adanya aliran permukaan 
yang hilang menjadi aliran bawah tanah atau sinking stream, dan ditemukan adanya mataair dengan debit yang besar. Berdasarkan aspek geomorfologi suatu kawasan karst biasanya dicirikan oleh kenampakan seperti sinkhole, drainase permukaan yang sedikit, lembah kering dan panjang, serta berkembangnya sungai bawah tanah. Salah satu kawasan atau bentanglahan karst yang sangat terkenal di Indonesia adalah karst Gunungsewu.

Karst Gunungsewu yang membentang dari Kabupaten Bantul, Daerah Istimewa Yogyakarta sampai dengan Kabupaten Pacitan, Provinsi Jawa Timur secara geologi tersusun oleh batugamping Formasi Wonosari. Batuan ini memiliki sifat yang mudah larut, sehingga terdapat sistem pergoaan di kawasan karst Gunungsewu (Cahyadi dkk., 2013b). Kawasan karst Gunungsewu yang telah berkembang menjadikan banyak dijumpai berbagai kenampakan-kenampakan yang unik dan layak untuk dikaji terutama dari aspek geomorfologi dan hidrologi karst (Cahyadi dkk., 2013c; Cahyadi dan Priadmodjo, 2015).

Salah satu kawasan di karst Gunungsewu yang memiliki kenampakan geomorfologi dan hidrologi karst yang beragam adalah kawasan karst sistem Pindul. Secara hidrologi, sistem karst pindul memiliki dua sistem hidrologi yakni sistem permukaan dan sistem bawah permukaan yang biasa disebut sistem sungai bawah tanah (SBT). Sistem sungai bawah tanah Pindul ini melewati beberapa goa yang berada di Kecamatan Karangmojo, Kabupaten Gunungkidul.

Yogyakarta sebagai kota pendidikan dan kota budaya telah lama menjadi pusat kegiatan belajar-mengajar generasi muda. Menurut data dari Kementrian Pendidikan dan Kebudayaan Republik Indonesia Tahun 2012, di Yogyakarta terdapat sekitar 126 perguruan tinggi negeri dan swasta. Jumlah mahasiswa sekitar 244.158 dan setiap tahunnya bertambah 55.196 mahasiswa baru. Diantara sekian banyak perguruan tinggi yang ada, terdapat beberapa perguruan tinggi yang memiliki jurusan yang sangat relevan dengan studi hidrologi dan geomorfologi karst. Jurusan tersebut di antaranya adalah Geografi, Geologi, Geofisika, Geodesi, Teknik Sipil, Teknik Lingkungan, Biologi, Kesehatan Lingkungan, Kehutanan, dan pertanian.

Banyaknya kampus dan mahasiswa yang meminati studi Hidrologi dan Geomorfologi Karst menjadi alasan pentingnya melakukan kajian tentang prospeksi kawasan Pindul sebagai kampus lapangan. Selain itu, letak yang relatif dekat dari pusat-pusat pendidikan, kelengkapan fenomena dan kajian, dan akses yang memadai menjadi fakta yang mendukung terciptanya kampus lapangan yang ideal. Kampus lapangan sangat bermanfaat guna 
mengaplikasikan ilmu-ilmu di kelas agar lebih meresap dan mengena pada mahasiswa.

\section{Metode Penelitian}

\section{Data, Alat dan Bahan}

Data yang dibutuhkan dalam penelitian ini terdiri dari data primer dan data sekunder. Data primer dan data sekunder yang dibutuhkan ditunjukkan pada Tabel 1. Alat survei yang dibutuhkan untuk mempermudah penelitian disertai dengan fungsi alat ditunjukkan pada Tabel 2. Bahan yang dibutuhkan untuk mempermudah penelitian disertai fungsi bahan ditunjukkan pada Tabel 3.

Tabel 1. Data yang Dibutuhkan

\begin{tabular}{|l|l|}
\hline \multicolumn{1}{|c|}{ Data Primer } & \multicolumn{1}{|c|}{ Data Sekunder } \\
\hline $\begin{array}{l}\text { Data lokasi kenampakan Hidrologi } \\
\text { dan Geomorfologi Karst }\end{array}$ & $\begin{array}{l}\text { Data pemetaan wilayah kajian } \\
\text { Data tentang fasilitas, sarana \& } \\
\text { prasarana sekitar objek }\end{array}$ \\
\hline
\end{tabular}

Tabel 2. Alat Penelitian

\begin{tabular}{|l|l|l|}
\hline No & \multicolumn{1}{|c|}{ Nama Alat } & \multicolumn{1}{c|}{ Fungsi } \\
\hline 1 & $\begin{array}{l}\text { GPS (Global Positioning } \\
\text { System) }\end{array}$ & $\begin{array}{l}\text { Mengetahui titik koordinat } \\
\text { pengukuran kedalaman muka } \\
\text { airtanah, titk sumber pencemar dan } \\
\text { sampel airtanah. }\end{array}$ \\
\hline 12 & Ceklist Lapangan & $\begin{array}{l}\text { Mencatat hasil pengamatan dan } \\
\text { pengukuran di lapangan }\end{array}$ \\
\hline 13 & Alat tulis dan Papan Jalan & $\begin{array}{l}\text { Menulis dan membantu pencatatan } \\
\text { data di lapangan }\end{array}$ \\
\hline 14 & Kamera & $\begin{array}{l}\text { Mengambil gambar/dokumentasi } \\
\text { lapangan }\end{array}$ \\
\hline
\end{tabular}


Tabel 3. Bahan Penelitian

\begin{tabular}{|c|l|l|}
\hline No & \multicolumn{1}{|c|}{ Nama Bahan } & \multicolumn{1}{c|}{ Fungsi } \\
\hline 1. & $\begin{array}{l}\text { Peta Rupa Bumi Indonesia } \\
\text { Lembar Karangmojo skala } \\
1: 25.000\end{array}$ & $\begin{array}{l}\text { Sebagai peta survei lapangan dan } \\
\text { informasi ketinggian tempat. }\end{array}$ \\
\hline 2 & $\begin{array}{l}\text { Data peta sistem Goa Pindul } \\
\text { dan sekitarnya }\end{array}$ & $\begin{array}{l}\text { Untuk mengetahui jaringan sistem } \\
\text { pergoaan, system hidrologi dan } \\
\text { geomorfologi di kawasan Pindul }\end{array}$ \\
\hline
\end{tabular}

\section{Teknis Penqumpulan Data}

Teknis pengumpulan data dalam penelitian ini dijelaskan pada Tabel 4. Data yang dibutuhkan meliputi data lokasi objek hidrologi dan geomorfologi, data karakteristik hidrologi dan geomorfologi serta wawancara dengan masyarakat di lokasi kajian.

Tabel 4. Teknis Pengumpulan Data Penelitian

\begin{tabular}{|c|c|c|}
\hline No & Data Penelitian & Teknis Pengumpulan Data \\
\hline 1. & $\begin{array}{l}\text { Data lokasi objek } \\
\text { kenampakan Hidrologi dan } \\
\text { Geomorfologi }\end{array}$ & $\begin{array}{l}\text { Melakukan pengumpulan data secara } \\
\text { manual pada checklist kemudian } \\
\text { direprentasikan dalam peta }\end{array}$ \\
\hline 2. & $\begin{array}{llr}\text { Pembuatan } & \text { Peta } & \text { Objek } \\
\text { Kenampakan } & \text { Hidrologi dan } \\
\text { Geomorfologi } & & \end{array}$ & $\begin{array}{l}\text { Kegiatan dilakukan dengan } \\
\text { memindahkan data koordinat lokasi } \\
\text { objek kenampakan ke dalam peta }\end{array}$ \\
\hline 3. & $\begin{array}{l}\text { Data } r \text { karakteristik } \\
\text { kenampakan objek Hidrologi } \\
\text { dan Geomorfologi Karst }\end{array}$ & $\begin{array}{lrr}\begin{array}{l}\text { Dilakukan } \\
\text { lapangan }\end{array} \text { dengan } & \text { observasi di } \\
\text { wawancara } & & \begin{array}{r}\text { melakukan } \\
\text { kepada }\end{array} \\
\text { masyarakat/pengelola } & \end{array}$ \\
\hline
\end{tabular}

\section{Teknis Analisis Data}

Teknik analisis atau metode analisis yang digunakan dalam penelitian ini adalah metode analisis deskriptif. Analisis deskriptif kualitatif berdasarkan observasi dan kajian pustaka yang dilakukan. Analisis deskriptif yang digunakan berupa analisis SWOT meliputi strengths (kekuatan), weaknesses (kelemahan), advantage (keuntungan), threats (ancaman) digunakan untuk menjelaskan objek atau kenampakan Hidrologi dan Geomofologi Karst yang dituangkan dalam bentuk peta dan gambar. Alur penelitian mengenai prospeksi kawasan Pindul sebagai kampus 
lapangan Hidrologi dan Geomofologi Karst disajikan dalam diagram alir penelitian pada Gambar 1.

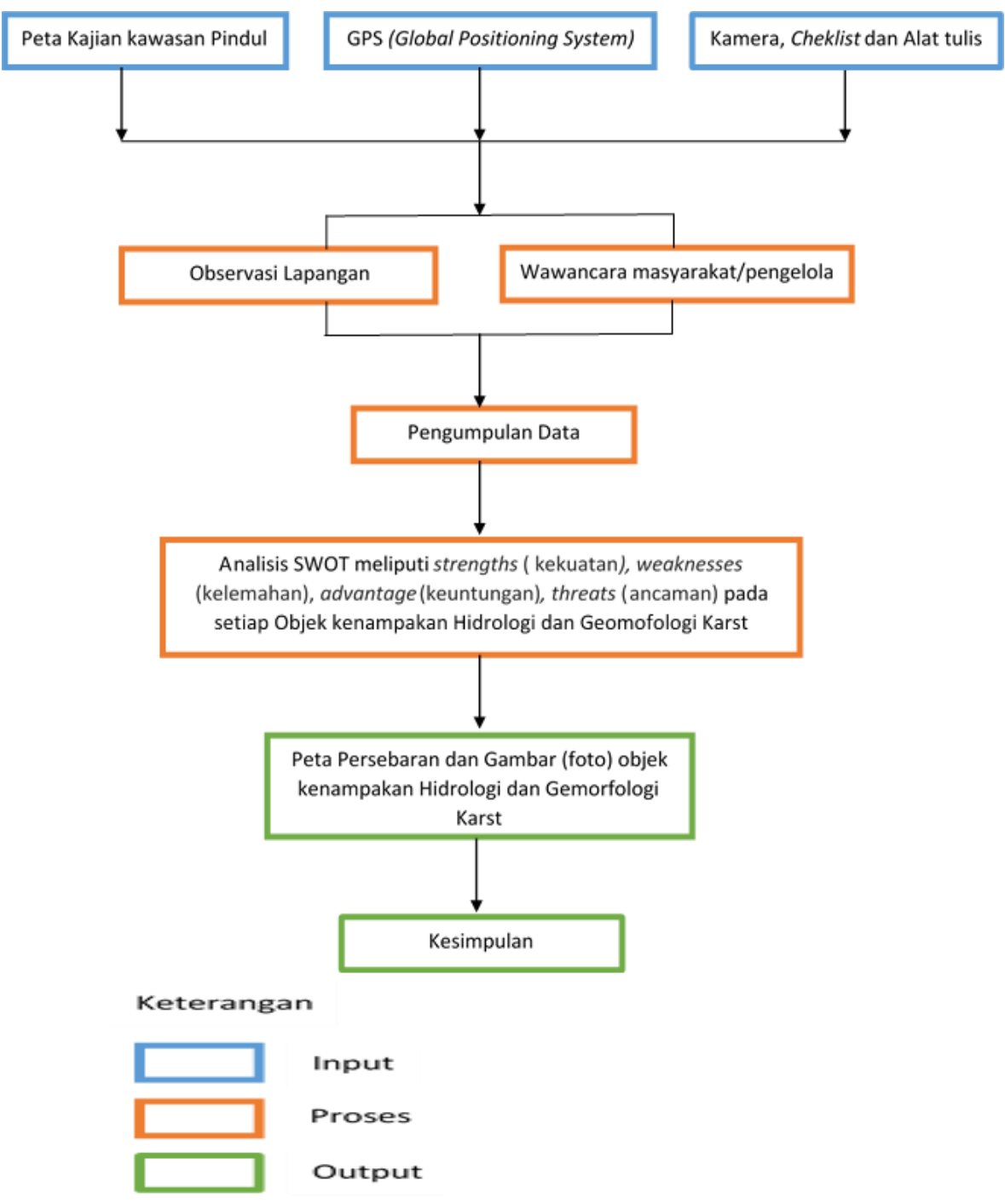

Gambar 1. Diagram Alir Penelitian

\section{Hasil dan Pembahasan}

Kenampakan objek atau fenomena Hidrologi dan Geomorfologi karst di kawasan Pindul sangat beragam, mulai dari kenampakan fisik sampai kenampakan sosial-budaya yang sangat beragam. Mataair (springs) adalah pemusatan pengeluaran airtanah yang muncul di permukaan tanah sebagai arus dari aliran air. Mataair dibedakan dengan rembesan (seepage). 
Rembesan adalah mataair yang keluar secara perlahan-lahan dan menyebar pada permukaan tanah (Rahardjo dkk., 2008). Terdapat lima mataair yang berhasil diidentifikasi yaitu 1) Mataair Mbeji, 2) Mataair Mudal, 3) Mataair Jebul, 4) Mataair Ngancar, 5) Mataair Gunung Abang. Kelima mataair ini memiliki karakteristik yang beragam.

\section{Mataair Mbeji}

Mataair Mbeji (Gambar 2) terletak di Kecamatan Karangmojo dengan koordinat 49M x:460947 y:9122370. Mataair Mbeji memiliki beberapa karakteristik. Disekitar mataair Mbeji penutup lahan berupa vegetasi rapat. Penggunaan lahan disekitar berupa kebun campuran dan sawah. Mataair mbeji digunakan masyarakat sebagai tempat untuk mencuci, mandi, sebagian untuk air munum dan digunakan sebagai sumber air pertanian. Kualitas fisik air pada mataair tidak berasa, tidak berbau, dan tidak berwarna. Berdasarkan hasil pengamatan dan wawancara terhadap masyarakat sekitar, diperoleh keterangan bahwa mataair Mbeji ini dibangun sejak jaman penjajahan Belanda. Masyarakat sekitar memiliki ritual adat untuk menjaga kelestarian mataair. Kegiatan pelestarian tersebut berupa melakukan pembersihan mataair secara rutin. Biasanya kegiatan bersihbersih dilakukan sehabis panen padi dalam rangka bersyukur kepada alam.

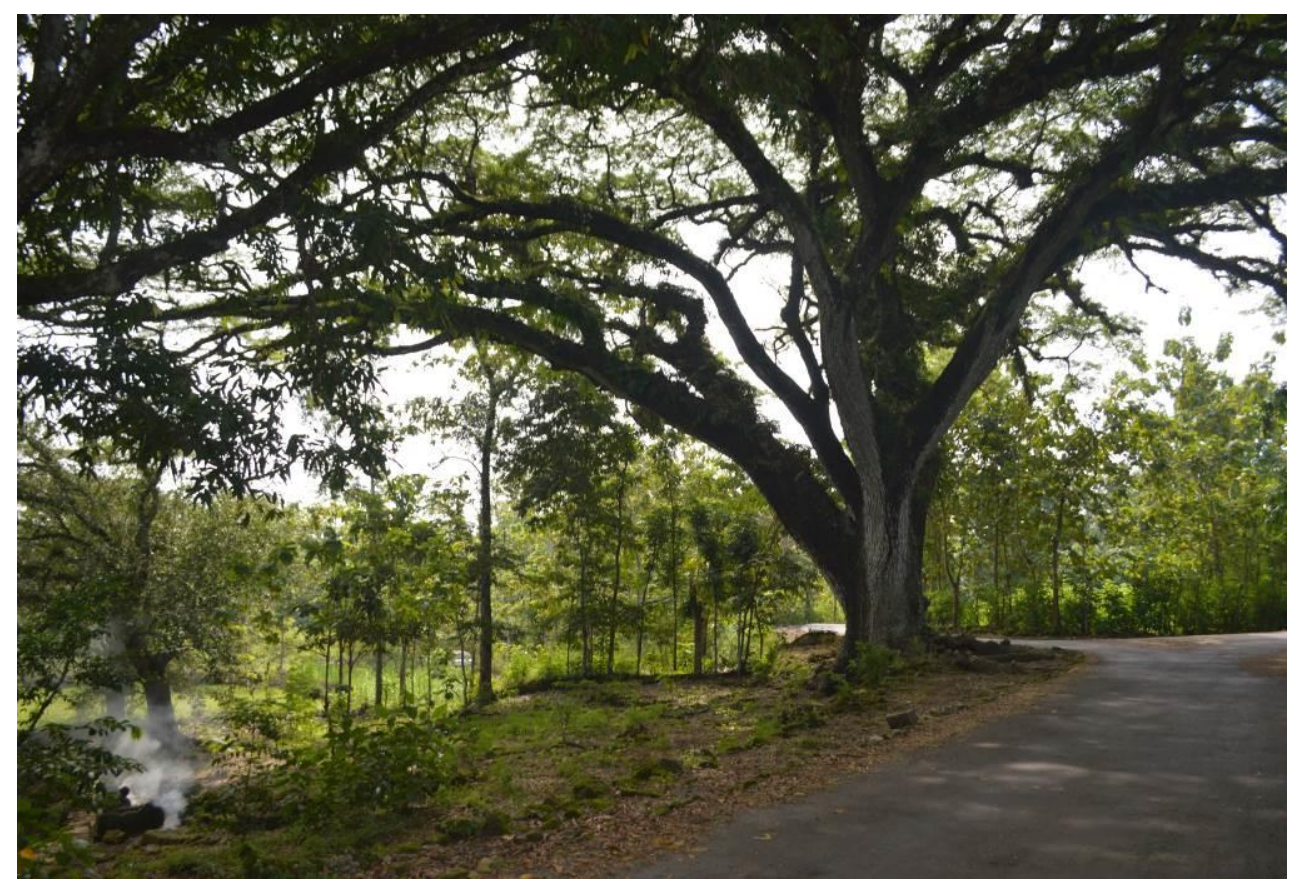

Gambar 1. Jalan menuju mataair Mbeji 


\section{Strengths (kekuatan)}

Kekuatan objek mataair Mbeji sebagai salah satu objek pengamatan dalam laboratorium alam adalah memiliki akses jalan yang baik. Sehingga memudahkan bagi mahasiswa/siswa/peneliti ketika menuju ke lokasi. Selain itu, lingkungan yang rindang semakin menambah kenyamanan ketika berada pada mataair.

\section{Advantage (keuntungan)}

Keuntungan jika mataair Mbeji menjadi salah satu objek dalam kawasan laboratorium lapangan hidrologi dan geomorfologi adalah adalah kelengkapan sarana mulai dari jalan, tempat yang dingin dan nyaman. Kondisi ini sangat kondusif untuk dijadikan tempat pembelajaran untuk mengindentifikasi fenomena yang ada.

\section{Weaknesses (kelemahan)}

Kelamahan jika mataair Mbeji dijadikan salah satu objek dalam kawasan laboratorium/kampus lapangan adalah kurang ada fasilitas pendukung seperti toilet/kamar mandi.

\section{Threats (ancaman)}

Berdasarkan kelemahan tersebut, maka objek mataair Mbeji sangat terancam dengan masalah kebersihan, karena tidak ada tempat bagi pengunjung untuk buang air dan sebagainya.

\section{Mataair Mudal}

Mataair Mudal (Gambar 3) terletak di Kecamatan yang sama dan dekat dengan mataair Mbeji yaitu di Kecamatan Karangmojo. Mataair Mudal terletak pada koordinat 49M x:461090 y:9122282. Disekitar mataair Mudal memiliki penutup lahan yaitu lahan kosong, bangunan dan vegetasi rapat. Penggunaan lahan disekitar berupa kebun campuran, sawah, dan terdapat tempat tambang kapur skala kecil. Kondisi mataair termasuk baik, air tidak berasa, berbau dan berwarna. Masyarakat biasa menggunakan mataair sebagai tempat mencuci, mandi dan sebagai sumber air irigasi bagi sawah disekitar mataair. 


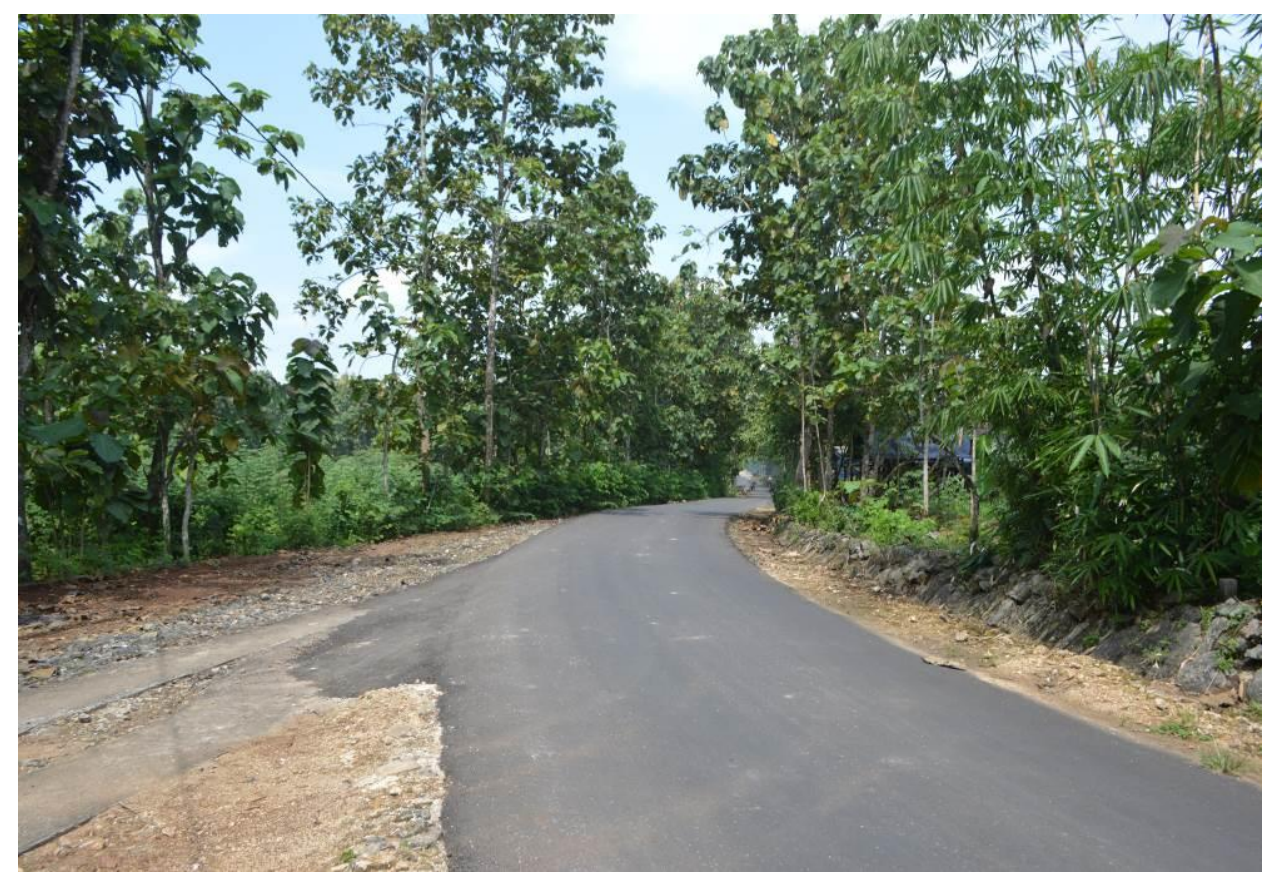

Gambar 3. Jalan menuju Mataair Mudal

\section{Strengths (kekuatan)}

Kekuatan dari objek mataair Mudal sebagai salah satu objek pada kampus lapangan adalah memiliki akses yang baik sehingga memudahkan untuk menuju lokasi. Kondisi jalan yang cukup besar sehingga bisa untuk dilewati bis kecil dan mobil.

\section{Advantage (keuntungan)}

Keuntungan jika mataair Mudal menjadi salah satu objek dalam kawasan laboratorium lapangan hidrologi dan geomorfologi adalah adalah kelengkapan sarana mulai dari jalan, tempat yang nyaman.

\section{Weaknesses (kelemahan)}

Kelamahan jika mataair Mudal dijadikan salah satu objek dalam kawasan laboratorium/kampus lapangan adalah kurang ada fasilitas pendukung seperti toilet/kamar mandi.

\section{Threats (ancaman)}

Berdasarkan kelemahan tersebut, maka objek mataair Mudal sangat terancam dengan masalah kebersihan, karena tidak ada tempat bagi pengunjung untuk buang air dan sebagainya. 


\subsection{Mataair Ngancar}

Mataair Ngancar (Gambar 4) terletak di Kecamatan Karangmojo. Mataair Ngancar terletak pada koordinat 49M x:461380 y:9123105. Disekitar mataair Ngancar memiliki penutup lahan yaitu lahan kosong, dan vegetasi rapat. Penggunaan lahan disekitar berupa kebun campuran. Kondisi mataair termasuk baik, air tidak berasa, berbau dan berwarna. Masyarakat biasa menggunakan mataair sebagai sumber air munum masyarakat. Mataair ini dilengkapi dengan fasilitas instalasi perpipaan untuk menyalurkan air minum kepada masyarakat.

\section{Strengths (kekuatan)}

Kekuatan objek mataair Ngancar untuk dijadikan objek kampus lapangan hidrologi dan geomorfologi kampus adalah keunikan proses hidrologi dan geomorfologi pada mataair tersebut. Mataair tersebut bersumber dari sungai bawah tanah yang muncul ke permukaan kemudian menyatu dengan sepenggal sungai permukaan dan selanjutnya kembali masuk menjadi aliran permukaan. Fasilitas yang ada cukup lengkap, sudah dilengkapi tangga untuk menuju ke lokasi.

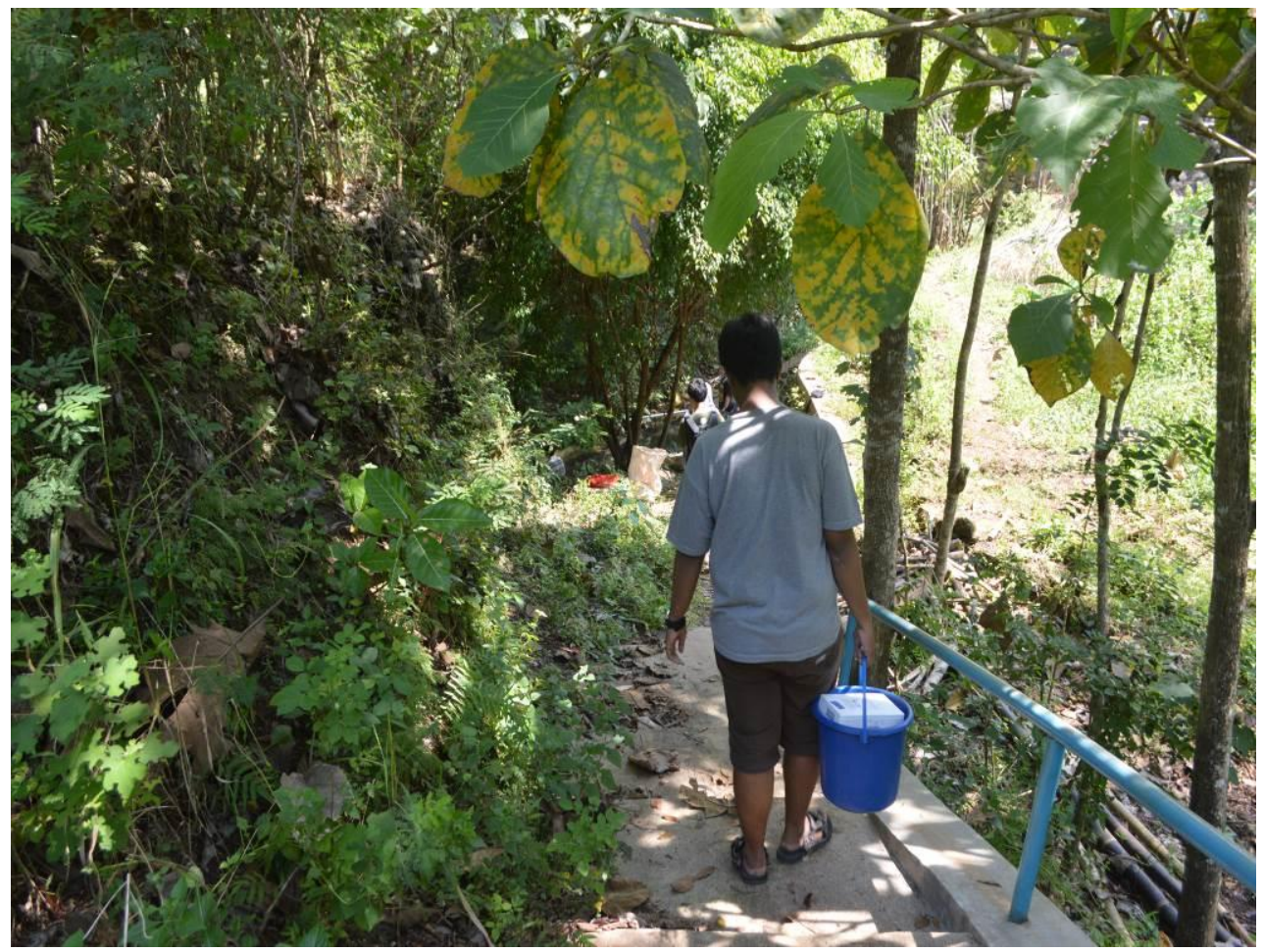

Gambar 4. Perjalanan menuju Mataair Ngancar 


\section{Advantage (keuntungan)}

Berdasarkan kekuatan yang dimiliki objek mataair Ngancar maka akan menghasilkan keuntungan untuk menjadi objek yang menarik untuk diteliti sebagai kawasan kampus lapangan.

\section{Weaknesses (kelemahan)}

Kelemahan yang ada pada objek mataair Ngancar jika dijadikan salah satu objek sebagai kampus lapangan hidrologi dan geomorfologi kampus adalah belum adanya jalan yang memadai, fasilitas wc/toilet perlu dibangun untuk mendukung seluruh kegiatan.

\section{Threats (ancaman)}

Berdasarkan kelemahan tersebut maka terdapat ancaman yaitu ketidaksiapan fasilitas jalan dan toilet yang dapat mengganggu kenyamanan dalam kegiatan ketika menjadi kampus lapangan hidroogi dan geomorfologi kampus.

\section{Sinking Stream Kedung Buntung}

Sinking stream Kedung Buntung (Gambar 5) merupakan terminologi untuk menyebutkan adanya sungai yang terpisahkan pada bawah permukaan dan memiliki masuk maupun keluar pada lubang/rekahan. Objek ini terletak di Kecamatan Karangmojo, dengan kordinat 49M x:461299 y:9123093. Secara umum kondisi objek ini menarik untuk dikaji tapi terdapat beberapa kendala terutama terkait dengan fasilitas pendukung sebagai sarana-prasarana kegiatan kampus lapangan.

\section{Strengths (kekuatan)}

Kekuatan dari objek ini berupa keunikan proses hidrologi dan geomorfologi yang dimiliki.

\section{Advantage (keuntungan)}

Berdasarkan kekuatan yang ada bisa dijadikan keuntungan untuk menarik minat para peneliti untuk mengkaji fenomena hidrologi dan geomorfologi karst.

\section{Weaknesses (kelemahan)}

Berdasarkan hasil pengamatan, terdapat beberapa kelemahan pada objek ini diantaranya belum tersedianya jalan yang memadai, fasilitas lain seperti sarana kebersihan juga tidak ditemukan. 


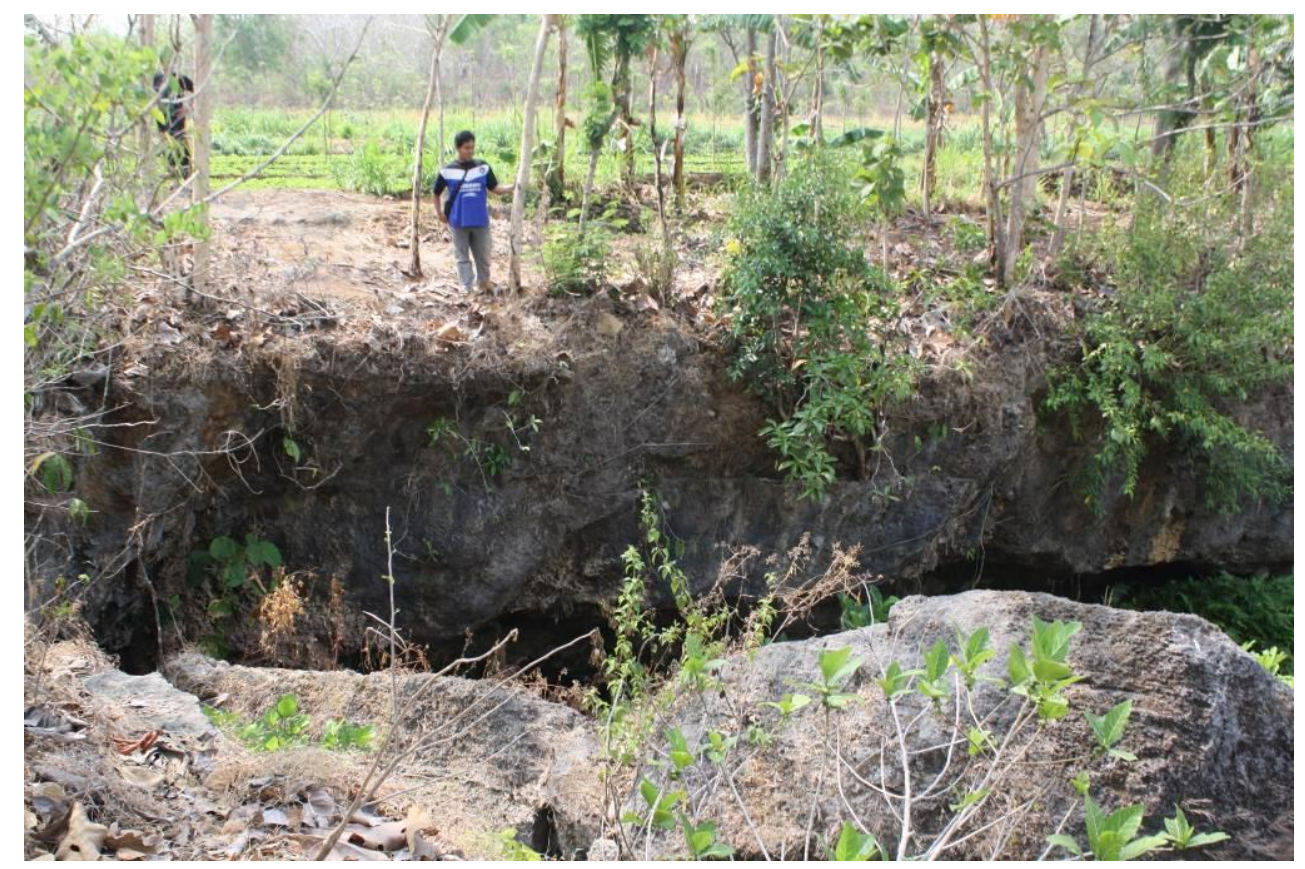

Gambar 5. Kenampakan sinking stream

\section{Threats (ancaman)}

Kondisi jalan yang kurang memadai bisa menjadi ancaman bagi objek sinking stream jika tidak dilakukan peningkatan demi tercipnya kampus lapangan hidrologi dan geomorfologi karst.

\section{Jembatan alam (Natural Bridge)}

Bentukan jembatan alami (natural bridge) (Gambar 6) adalah sebuah suatu bentukan yang lebih pendek dari tunnel dan lebih condong untuk tempat dilewati nya udara atau air. Natural bridge masih terletak di Kecamatan Karangmojo. Kondisi penutup lahan berupa vegetasi rapat dengan penggunaan lahan sebagai semak belukar.

\section{Strengths (kekuatan)}

Kekuatan dari objek ini berupa keunikan proses hidrologi dan geomorfologi yang dimiliki.

\section{Advantage (keuntungan)}

Berdasarkan kekuatan yang ada bisa dijadikan keuntungan untuk menarik minat para peneliti untuk mengkaji fenomena hidrologi dan geomorfologi karst. 


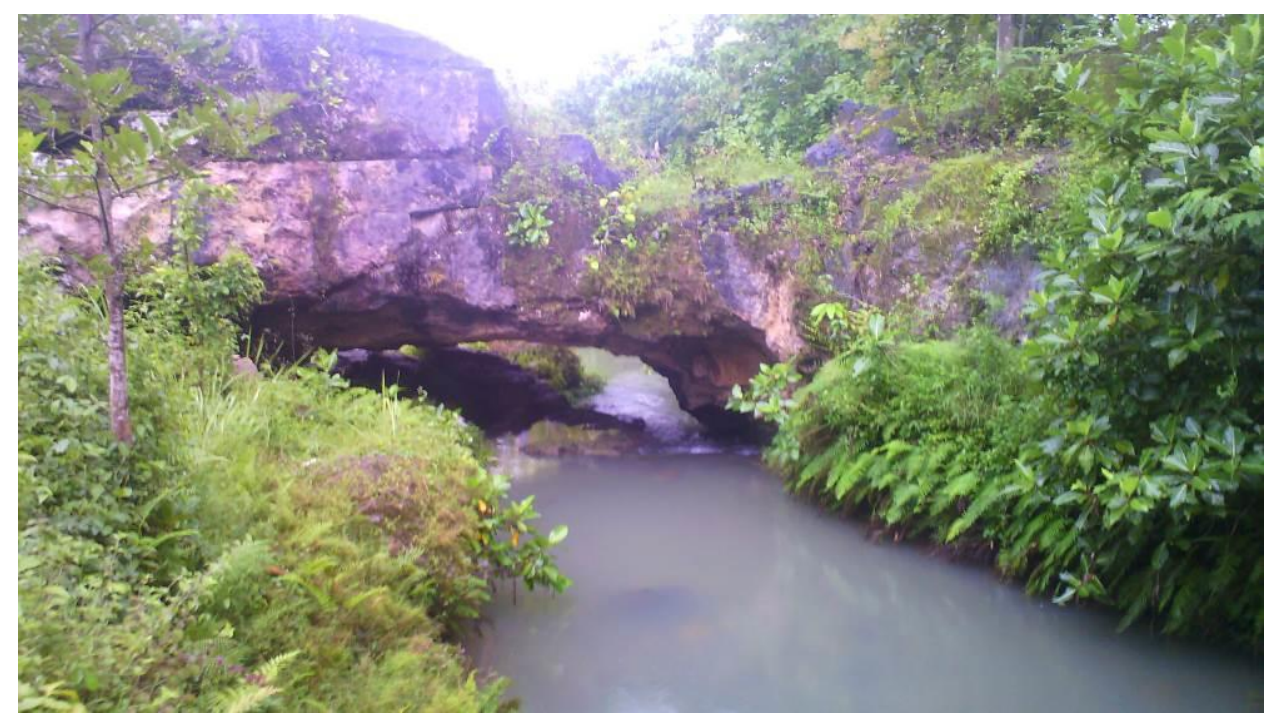

Gambar 6. Kenampakan natural bridge

\section{Weaknesses (kelemahan)}

Berdasarkan hasil pengamatan, terdapat beberapa kelemahan pada objek ini diantaranya belum tersedianya jalan yang memadai, fasilitas lain seperti sarana kebersihan juga tidak ditemukan.

\section{Threats (ancaman)}

Kondisi jalan yang kurang memadai bisa menjadi ancaman bagi objek jika tidak dilakukan peningkatan fasilitas menuju lokasi. Selain itu, perlu juga diperhatian jumlah pengunjung objek ini untuk mencegah kerusakan objek.

\section{Collapse Doline (Goa Suruh)}

Collapse doline merupakan salah satu bentukan di kawasan karst. Collapse doline adalah sebuah bentukan depresi terbuka yang terjadi akibat runtuhan atap goa. Collapse doline ini terletak diantara kedua mulut Goa Suruh. Mulut Goa Suruh (Gambar 7) ini berhadapan atau berlawanan arah terbentuk karena adanya collapse. Lorong goa ini merupakan lorong horizontal dengan kondisi aliran sepanjang tahun. Letak mulut Goa Suruh 1 ini berada pada koordinat 49M 461621 dan 9122745 dengan dimensi mulut goa $18,48 \mathrm{~m}^{2} 56,16 \mathrm{~m}^{2}$ dengan arah aliran airtanahnya mengarah ke Goa Candi. 


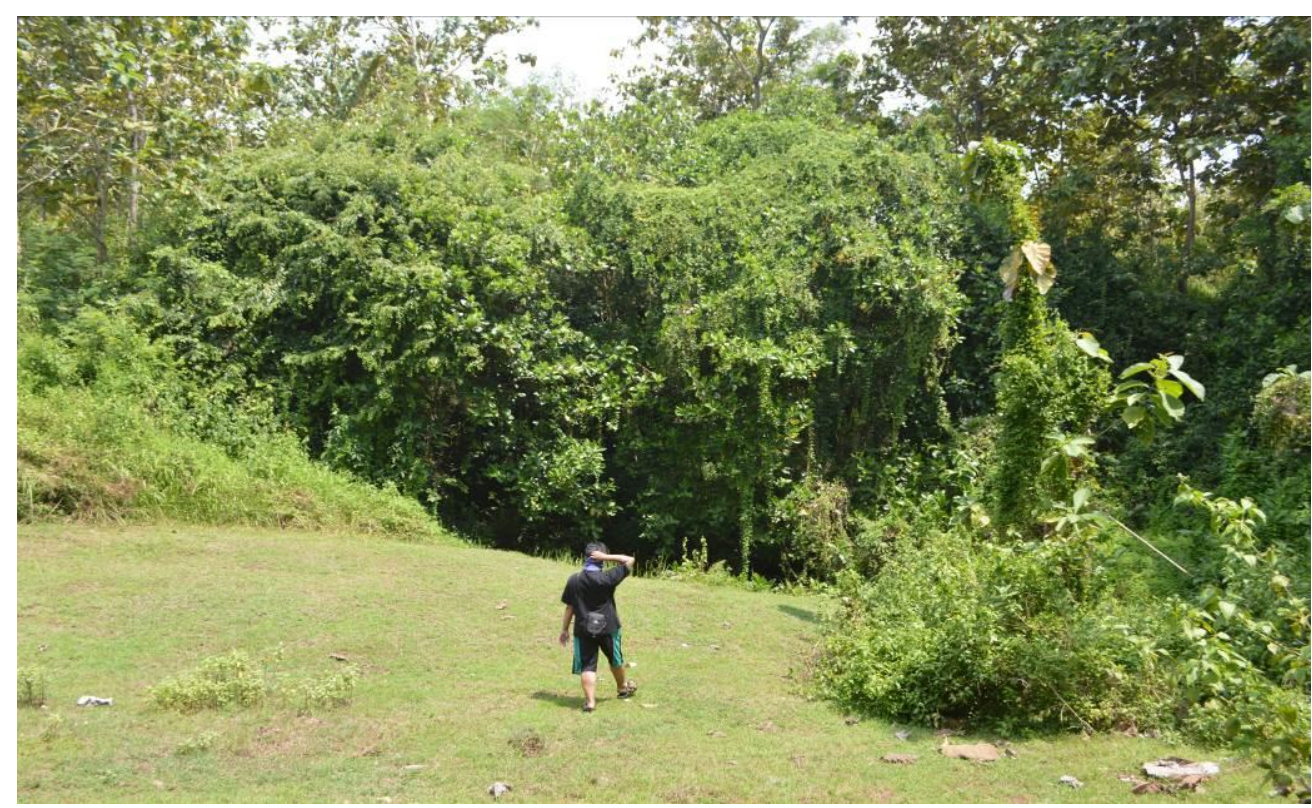

Gambar 7. Collapse Doline

\section{Strengths (kekuatan)}

Kekuatan dari objek ini berupa keunikan proses hidrologi dan geomorfologi yang dimiliki. Runtuhan atap goa yang runtuh menjadi objek yang sangat unik karena secara langsung dapat melihat kenampakan di dalam goa tanpa harus menyusuri nya sepeti aliran air bawah tanah yang melalui nya.

\section{Advantage (keuntungan)}

Berdasarkan kekuatan yang ada bisa dijadikan keuntungan untuk menarik minat para peneliti untuk mengkaji fenomena hidrologi dan geomorfologi karst.

\section{Weaknesses (kelemahan)}

Berdasarkan hasil pengamatan, terdapat beberapa kelemahan pada objek ini diantaranya belum tersedianya jalan yang memadai, fasilitas lain seperti sarana kebersihan juga tidak ditemukan.

\section{Threats (ancaman)}

Kondisi jalan yang kurang memadai bisa menjadi ancaman bagi objek jika tidak dilakukan peningkatan fasilitas menuju lokasi. Selain itu, 
perlu juga diperhatian jumlah pengunjung objek ini untuk mencegah kerusakan objek.

\section{Goa Pindul}

Goa Pindul (Gambar 8) terletak di Dusun Gelaran I, Desa Bejiharjo, Kecamatan Karangmojo. Goa pindul merupakan goa horizontal. Goa Pindul ini memiliki panjang lorong kurang lebih 300 meter dengan jarak muka airtanah dengan langit-langit goa berkisar antara $4-6$ meter serta dengan kedalaman airtanah yang cukup bervariasi dari 2 meter hingga mencapai 10 meter di bagian zona gelap abadinya. Pintu masuk mulut goa ini terletak pada koordinat 49 M 461378 dan 9123509, serta lorong dari Goa Pindul akan keluar di koordinat 461209 dan 9123681.

\section{Strengths (kekuatan)}

Kekuatan dari objek ini berupa keunikan proses hidrologi dan geomorfologi yang dimiliki. Selain itu, akses, fasilitas keamanan, kebersihan dan sarana lainnya sangat lengkap dan memadai. Hal ini karena Goa Pindul dikelola dengan baik oleh penggiat wisata goa.

\section{Advantage (keuntungan)}

Berdasarkan kekuatan yang ada bisa dijadikan keuntungan untuk menarik minat para peneliti untuk mengkaji fenomena hidrologi dan geomorfologi karst. Disamping itu, Goa pindul juga sudah terkenal sebagai objek wisata Goa yang menarik. Hal ini bisa menjadi daya tarik tersendiri bagi peneliti jika ingin mengembangkan objek ini sebagai kawasan kampus lapangan.

\section{Weaknesses (kelemahan)}

Berdasarkan hasil pengamatan, terdapat beberapa kelemahan pada objek ini yaitu kawasan Goa Pindul sangat padat oleh pengunjung karena merupakan objek wisata terkenal. Adanya pengunjung yang sangat banyak akan mengganggu tingkat konsentrasi dan kenyamanan belajar. Selain itu, dengan banyaknya pengunjung dikhawatirkan akan mengganggu ekosistem alami goa.

\section{Threats (ancaman)}

Kerusakan ekosistem akibat aktivitas wisata yang melebihi kapasitas harus diperhatikan, mengingat tren wisata Goa Pindul terus meningkat. Jika ekosistem Goa rusak maka kegiatan eksplorasi alam di kampus lapangan menjadi tidak menarik. 


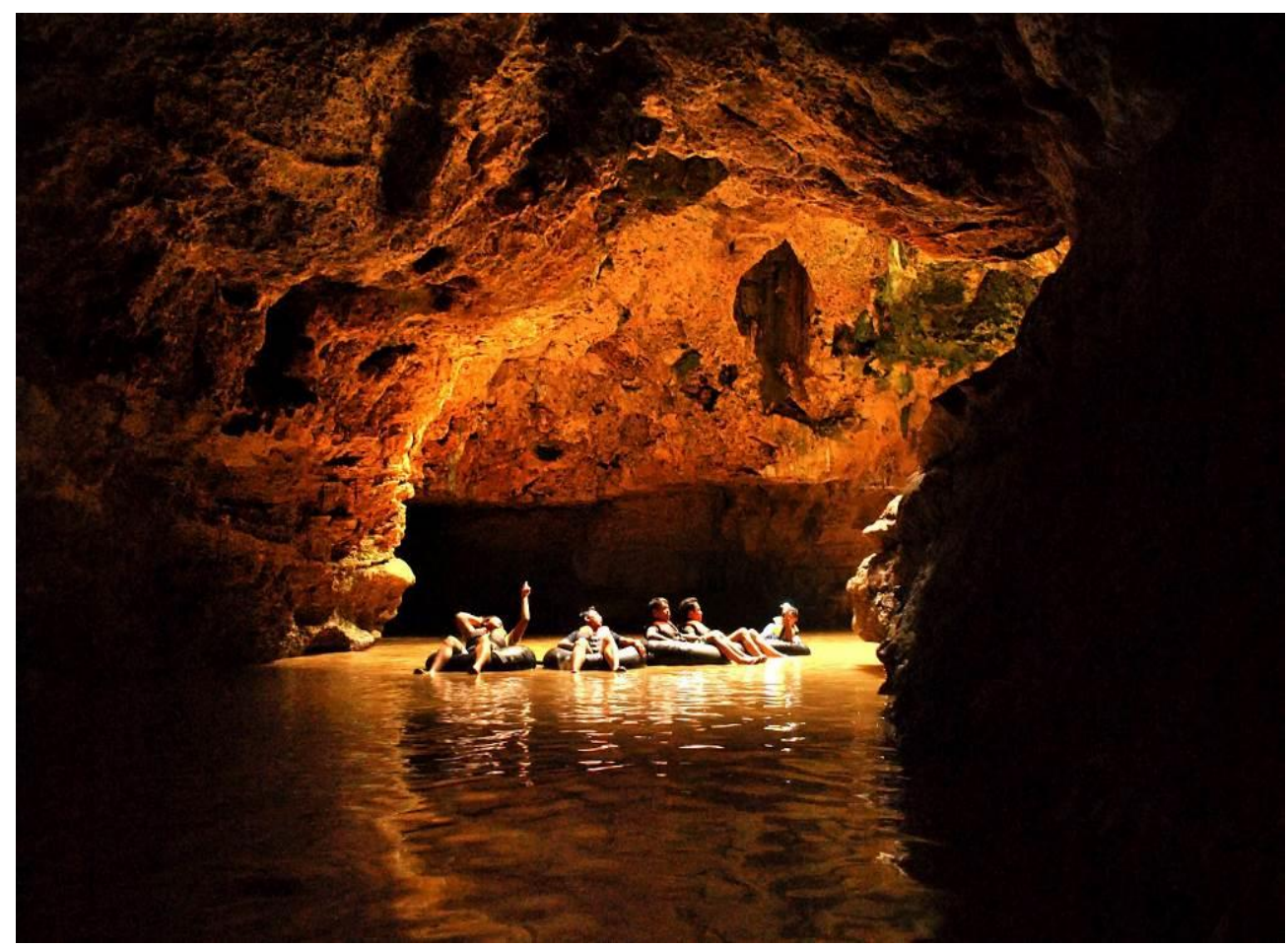

Gambar 8. Aktivitas wisata di Goa Pindul (www.goapindul.org)

\section{Sinkhole Goa Emas}

Sinkhole atau yang biasa dikenal dengan ponor merupakan bentukan depresi seperti lubang yang menjadi pintu masuk bagi system aliran bawah tanah. Goa Emas merupakan lorong vertikal dari sistem Goa Asri-Greng. Lorong vertikal ini setinggi 6,2 meter dengan dimensi mulut goa sebesar 7,92 $\mathrm{m}^{2}$ berada pada koordinat 49M 462444 dan 9123031 . Mulut goa ini berada berdekatan dengan Goa Greng. Disaat terjadi hujan, mulut goa Emas menjadi pintu masuk bagi air menuju system sungai bawah tanah.

\section{Strengths (kekuatan)}

Kekuatan dari objek ini berupa keunikan proses hidrologi dan geomorfologi yang dimiliki.

\section{Advantage (keuntungan)}

Berdasarkan kekuatan yang ada bisa dijadikan keuntungan untuk menarik minat para peneliti untuk mengkaji fenomena hidrologi dan geomorfologi karst. 


\section{Weaknesses (kelemahan)}

Berdasarkan hasil pengamatan, terdapat beberapa kelemahan pada objek ini diantaranya belum tersedianya jalan yang memadai, fasilitas lain seperti sarana kebersihan juga tidak ditemukan.

\section{Threats (ancaman)}

Kondisi jalan yang kurang memadai bisa menjadi ancaman bagi objek jika tidak dilakukan peningkatan fasilitas menuju lokasi.

\section{Situs Arkeologi Gondang}

Situs arkeologi Gondang (Gambar 9) berada di dusun Gondang, desa Ngawis, kecamatan Karangmojo dengan kordinat $49 \mathrm{M}$ x:462657 y:9122457. Situs Gondang merupakan situs penginggalan purbakaladari zaman batu besar atau Megalitikum. Peninggalan prurbakala yang terdapat di lokasi ini berjenis kubur batu. Menurut narasumber lokasi ini ditemukan pada tahun 1970-an dan mulai dipugar oleh pemerintah pada tahun 1996 oleh Suaka Peninggalan Sejarah dan Purbakala DI Yogyakarta. Kondisi di sekitar situs Gondang merupakan permukiman dan kebun milik warga. Situs gondang sendiri sering dirawat dan dikeramatkan oleh warga sekitar demi lestarinya situs ini.

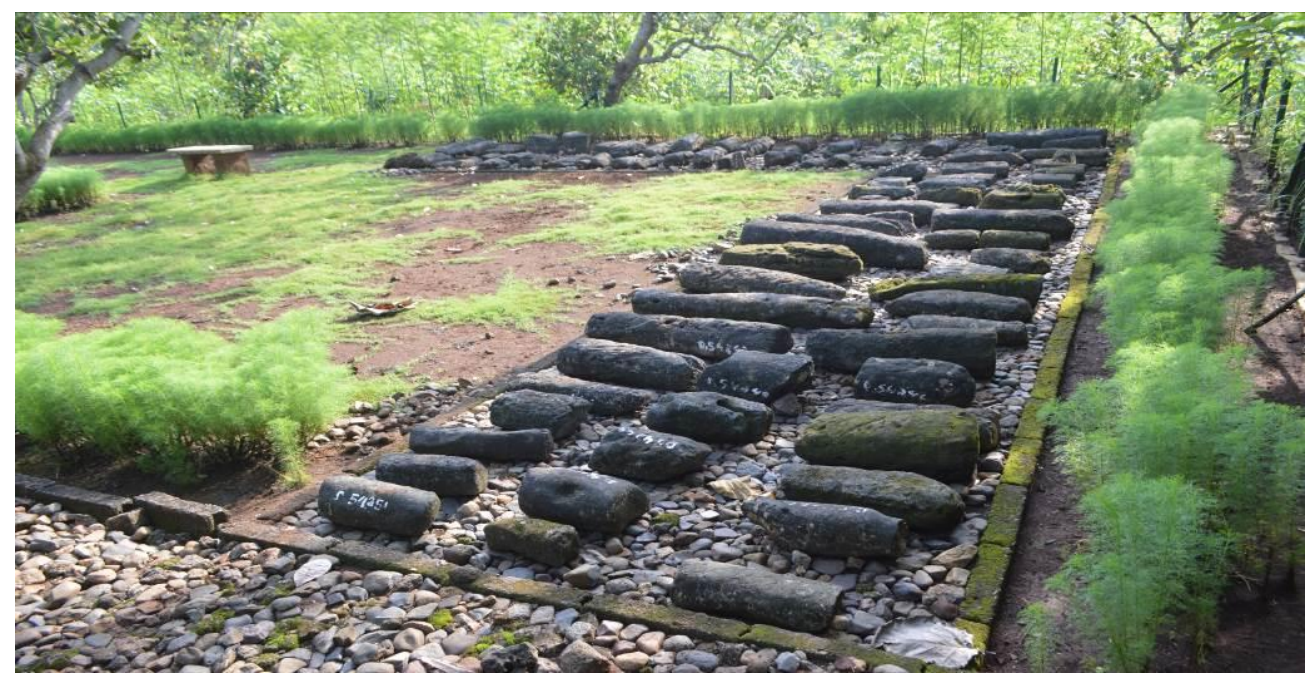

Gambar 9. Peninggalan Purbakala Situs Gondang

\section{Strengths (kekuatan)}

Kekuatan dari objek ini adalah nilai sejarah yang besar. Situs purbakala tidak bisa dijumpai di sembarang tempat sehingga ini menjadi kenunikan tersendiri. 


\section{Advantage (keuntungan)}

Berdasarkan kekuatan yang ada bisa dijadikan keuntungan untuk menarik minat para peneliti untuk mengkaji fenomena sejarah masa lampau yang berada di kawasan karst.

\section{Weaknesses (kelemahan)}

Berdasarkan hasil pengamatan, terdapat beberapa kelemahan pada objek ini diantaranya belum tersedianya jalan yang memadai, sarana parkir, keterangan/informasi benda purbakala, dan juga fasilitas lain seperti sarana kebersihan juga tidak ditemukan.

\section{Threats (ancaman)}

Kondisi jalan yang kurang memadai, tidak adanya informasi mengenai benda purbakala, lahan parkir terbatas bisa menjadi ancaman bagi objek jika tidak dilakukan peningkatan fasilitas menuju lokasi.

\section{Situs Arkeologi Sokoliman}

Situs arkeologi Sokoliman berada di dusun Sokoliman, desa Bejiharjo, kecamatan Karangmojo dengan kordinat 49M x:462018 y:M. Situs Sokoliman ini menurut catatan Balai Arkeologi Yogyakarta termasuk salah satu Cagar Budaya Situs Megalitikum yang sporadis tersebar di kawasan Gunungkidul. Wujud fisik situs ini hanyalah berupa kumpulan batu-batu yang saat ini sudah tertata rapi dan diberi kode identifikasi di atas tanah yang sudah diratakan dan diberi batas dengan concrete-blok.

Sebaran situs megalitikum di Gunungkidul mencakup beberapa lokasi yang tampaknya berpola tidak jauh-jauh berada di sepanjang aliran Kali Oya. Tercatat beberapa situs seperti di Gondang, Sokoliman, Gunungbang, Kajar, Wonobuda, dan Bleberan. Diluar DAS Oya memang terdapat pula situs megalitikum, seperti di Goa Braholo di daerah selatan Gunungkidul. Berdasarkan riset para peneliti yang dilakukan tahun 1934 tersebut menunjukkan bahwa situs-situs megalitikum termasuk Situs Sokoliman ini teridentifikasi sebagai kompleks kubur peti batu. Pada kubur peti batu di Kajar ditemukan 35 individu bertumpukan pada kedalaman $80 \mathrm{~cm}$ dengan bekal kubur beberapa alat dari besi berupa arit. Temuan lain berupa cincin perunggu dan sebuah mangkok terakota atau gerabah (www.jogjatrip.com). Kondisi di sekitar situs berupa permukiman dan ladang tanaman kayu putih. 


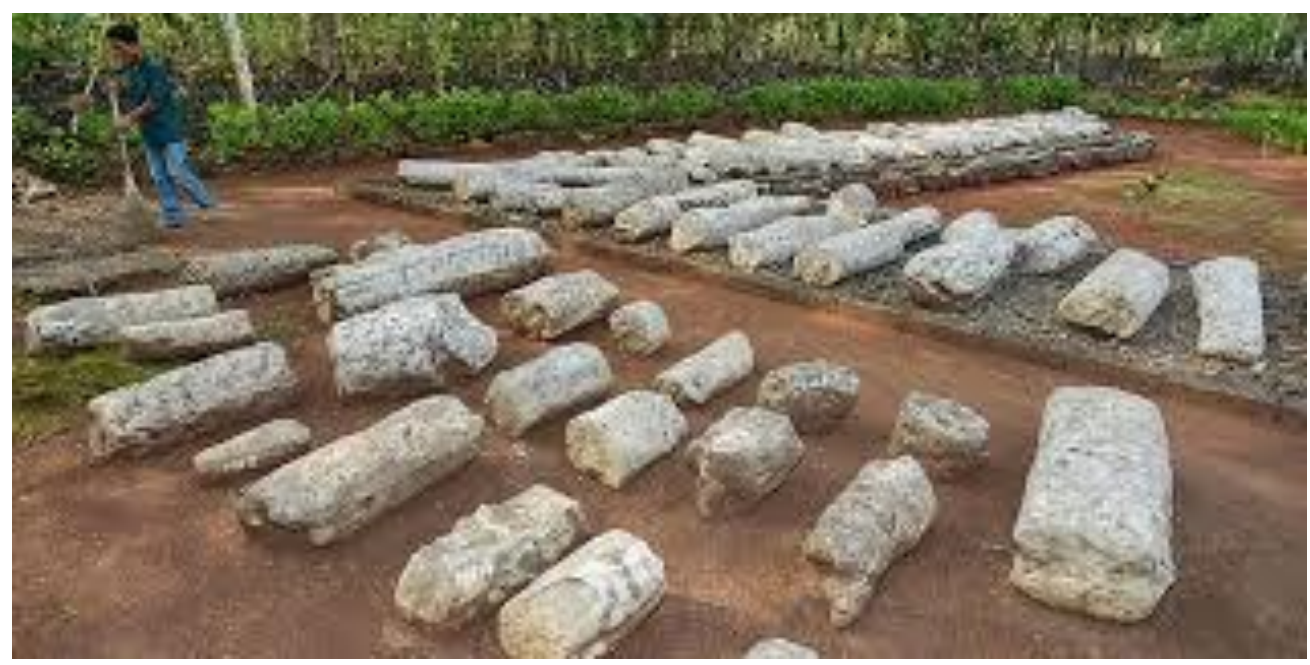

Gambar 9. Situs Arkeologi Sokoliman (www.travel.kompas.com)

\section{Strengths (kekuatan)}

Kekuatan dari objek ini adalah nilai sejarah yang besar. Situs purbakala tidak bisa dijumpai di sembarang tempat sehingga ini menjadi kenunikan tersendiri. Selain itu pada situs ini sudah dilengkapi dengan fasilitas yang memadai seperti jalan aspal yang mulus dari kota wonosari ke lokasi situs.

\section{Advantage (keuntungan)}

Berdasarkan kekuatan yang ada bisa dijadikan keuntungan untuk menarik minat para peneliti untuk mengkaji fenomena sejarah masa lampau yang berada di kawasan karst. Kondisi jalan aspal yang baik sangat bermanfaat untuk memudahkan akses menuju lokasi.

\section{Weaknesses (kelemahan)}

Berdasarkan hasil pengamatan tidak ditemukan kelemahan yang berarti. Hanya saja perlu terus dikembangkan agar bisa menjadi tujuan atau destinasi situs purbakala yang baik.

\section{Threats (ancaman)}

Tidak terdapat ancaman yang berarti pada situs ini. Hanya saja jika melakukan kegiatan pada lokasi ini

\section{Pabrik Pengolahan Minyak Kayu Sendangmole}

Pabrik pengolahan minyak kayu putih PT. Sendangmole (Gambar 10) berada di Sendangmole, Playen, Gunungkidul. PT Sendangmole mengolah lahan yang berada dibawah BDH (Bagian Daerah Hutan) Playen. 
BDH Playen yaitu pabrik Sendangmole yang dapat memanen daun kayu putih sebanyak 18 ton / hari. Dari setiap ton ton daun kayu putih yang di panen dapat menghasilkan minyak kayu putih \pm (kurang lebih) 7 - 9 liter. Adanya hutan produksi Playen berakibat pada peningkatan penghasilan masyarakat serta secara tidak langsung ikut melakukan kegiatan penghijauan hutan.

\section{Strengths (kekuatan)}

Kekuatan dari objek ini adalah pembelajaran mengenai pengelolaan hutan produksi kayu putih. Pengunjung bisa belajar mengenai cara menanam kayu putih, cara panen, hingga cara pengolahannya menjadi minyak kayu putih. Kondisipabrik cukup baik dan terawatt meski sudah berdiri sejak lama. Akses menuju pabrik juga sangat mudah.

\section{Advantage (keuntungan)}

Berdasarkan kekuatan yang ada bisa dijadikan keuntungan untuk menarik minat para peneliti untuk mengkaji pemanfaatan dan pengelolaan kawasan hutan produksi kayu putih. Kondisi pabrik yang terawatt dan jalan aspal yang baik sangat bermanfaat untuk memudahkan akses menuju lokasi.

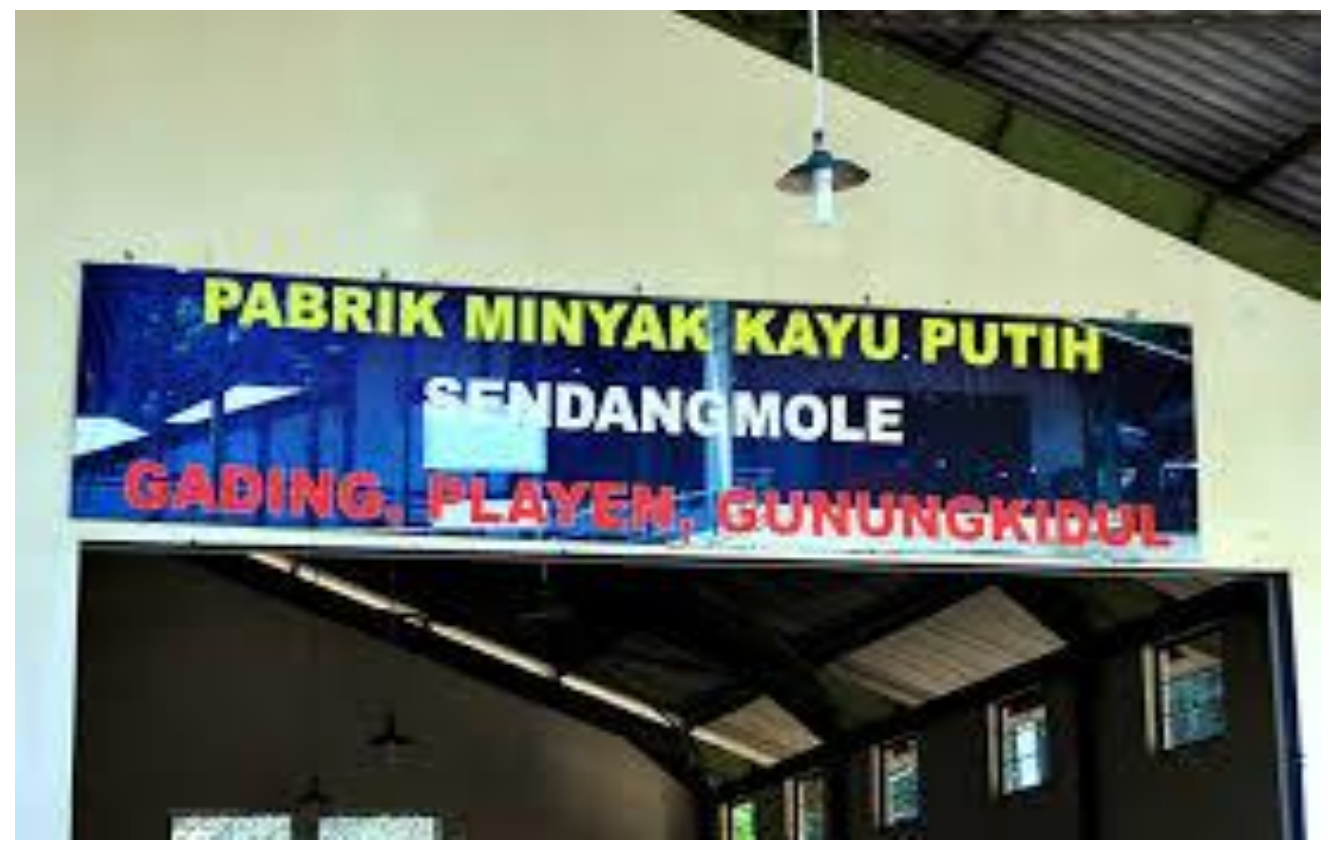

Gambar 10. Lokasi Pabrik Sendangmole 


\section{Weaknesses (kelemahan)}

Berdasarkan hasil pengamatan tidak ditemukan kelemahan yang berarti. Hanya saja perlu terus dikembangkan agar bisa menjadi tujuan pembelajaran yang baik dalam pengelolaan hutan produksi kayu putih.

\section{Threats (ancaman)}

Tidak terdapat ancaman yang berarti pada objek ini. Hanya saja jika melakukan kegiatan pada lokasi ini.

Hasil inventarisasi data kemudian disusun dalam sebuah peta Gambar 11. Gambar 11 menunjukkan 11 lokasi di wilayah kajian yang memiliki potensi menjadi situs untuk kajian Hidrologi dan Geomorfologi kawasan karst.

\section{Kesimpulan}

Berdasarkan hasil kajian yang dilakukan, maka disimpulkan beberapa hal berikut ini:

1. Secara garis besar seluruh objek tersebut layak untuk dijadikan kampus lapangan hidrologi dan geomorfologi karst kawasan Pindul.

2. Kawasan karst Pindul terdapat beberapa objek yang di prospeksikan menjadi kampus lapangan hidrologi dan geomorfologi karst yaitu mataair Mbeji, mataair Mudal, mataair Ngancar, Sinking Stream, Natural Bridge, Collapse Doline, Goa Pindul, Sinkhole Goa Emas, Situs Arkeologi Gondang, Situs Arkeologi Sokoliman dan pabrik pengolahan minyak kayu putih Sendangmole.

3. Hasil identifikasi direpresentasikan dalam bentuk peta persebaran objek pengamatan di kawasan karst Pindul.

\section{Pengakuan}

Penelitian ini merupakan bagian dari hibah Penelitian Unggulan Perguruan Tinggi (PUPT) Kementerian Riset, Teknologi dan Pendidikan Tinggi (Kemenristekdikti) tahun 2016 yang berjudul "Karakterisasi Hidrologi dan Banjir di Sungai Bawah Tanah Goa Pindul untuk Pengelolaan Pariwisata Berkelanjutan Berbasis Manajemen Kebencanaan" dengan nomor kontrak 679/UN1P.III/LT/DIT-LIT/2016. 


\section{PETA PERSEBARAN OBJEK SEBAGAI PROSPEKSI KAMPUS LAPANGAN HIDROLOGI DAN GEOMORFOLOGI KARST KAWASAN PINDUL}

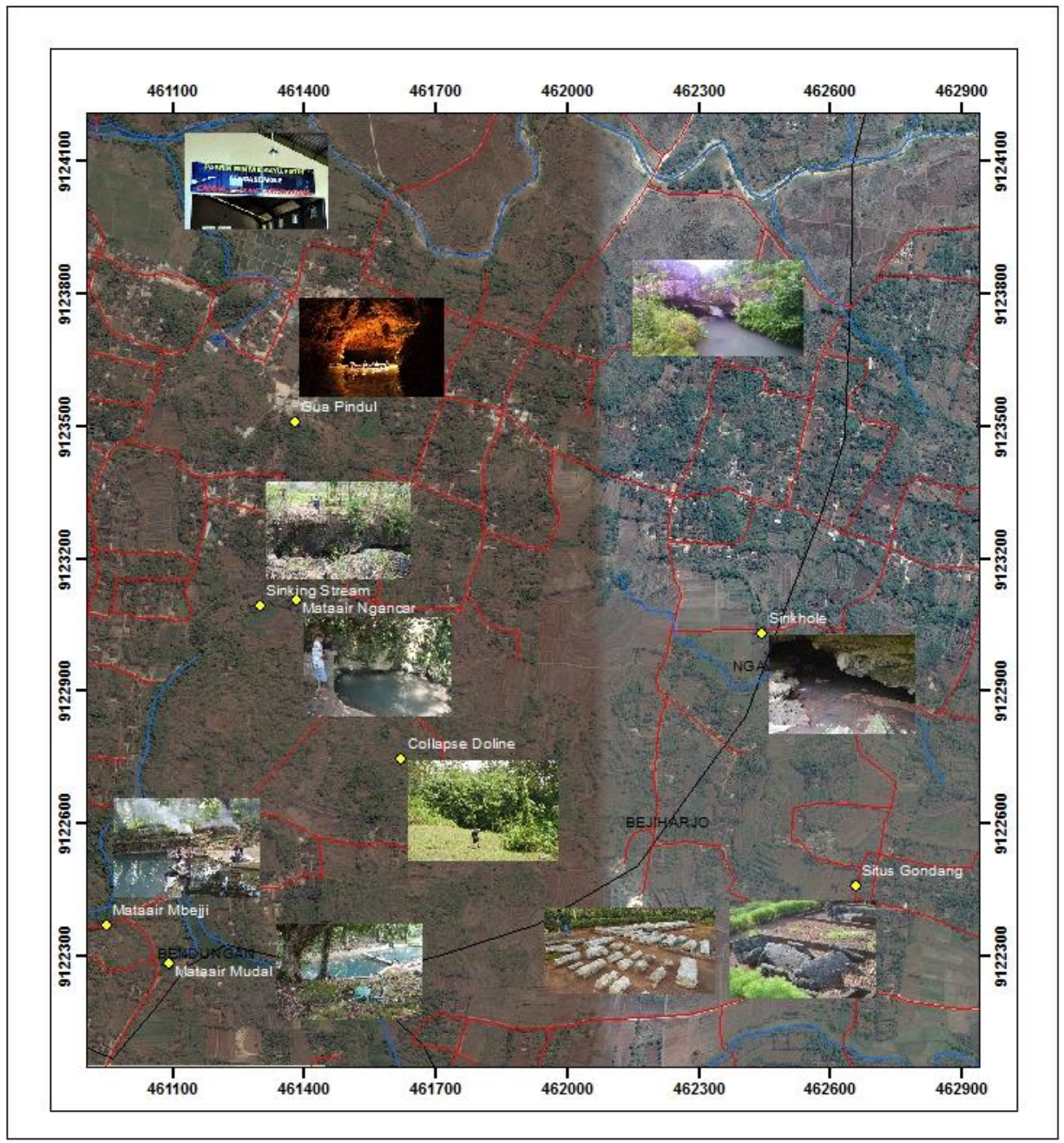

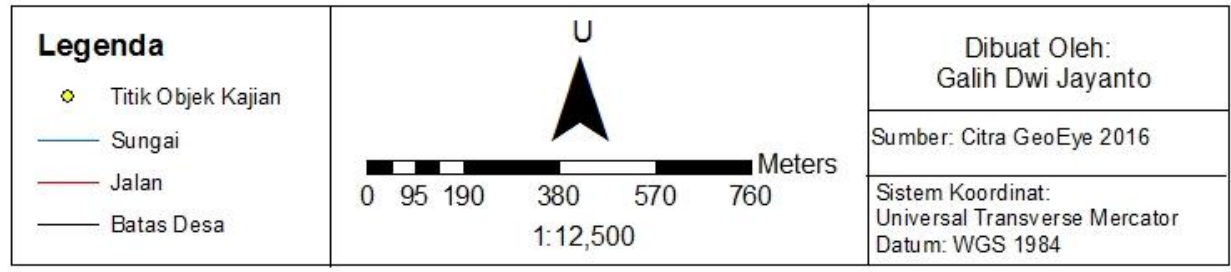

Gambar 11. Peta Persebaran Objek Pengamatan 


\section{Daftar Pustaka}

Cahyadi, A. 2010. Pengelolaan Kawasan Karst dan Peranannya dalam Siklus Karbon di Indonesia. Prosiding Seminar Nasional Perubahan Iklim. Yogyakarta: Sekolah Pascasarjana Universitas Gadjah Mada.

Cahyadi, A.; Prabawa, A. dan Putranto, S.A. 2013a. Pengelolaan Kawasan Karst Gunungsewu Sebagai Upaya Melestarikan Fungsi Penyerapan Karbondioksida. dalam Marfai, M.A. dan Widyastuti, M. 2013. Pengelolaan Lingkungan Zamrud Khatulistiwa. Yogyakarta: Pintal.

Cahyadi, A.; Ayuningtyas, E.A. dan Prabawa, B.A. 2013b. Urgensi Pengelolaan Sanitasi dalam Upaya Konservasi Sumberdaya Air di Kawasan Karst Gunungsewu Kabupaten Gunungkidul. Indonesian Journal of Conservation, 2(1): 23-32.

Cahyadi, A.; Pratiwi. E.S. dan Fatchurohman, H. 2013c. Metode-metode Identifikasi Karakteristik Daerah Tangkapan Air Sungai Bawah Tanah dan Mata Air Kawasan Karst: Suatu Tinjauan. dalam Marfai, M.A. dan Widyastuti, M. 2013. Pengelolaan Lingkungan Zamrud Khatulistiwa. Yogyakarta: Pintal.

Cahyadi, A. 2014. Keunikan Hidrologi Kawasan Karst: Suatu Tinjauan. dalam Cahyadi, A.; Prabawa, B.A.; Tivianton, T.A. dan Nugraha, H. 2014. Ekologi Lingkungan Kawasan Karst Indonesia: Mejaga Asa Kelestarian Kawasan Karst Indonesia, Edisi 2. Yogyakarta: Deepublish.

Cahyadi, A. dan Priadmodjo, A. 2015. Pengaruh Penambangan Gamping terhadap Fungsi Penyerapan Karbondioksida $\left(\mathrm{CO}_{2}\right)$ Atmosfer di Kawasan Karst Kecamatan Ponjong, Kabupaten Gunungkidul. Prosiding Seminar Nasional Geospasial Day. Surakarta: Universitas Sebelas Maret.

Gilli, E. 2015. Karstology Karst, Caves and Spring. London : CRC Press Taylor \& Francis Group.

Kemendikbud. 2011. Data Statistik Perguruan Tinggi tahun 2011-2012. Jakarta: Sekjen Kemendikbud RI

Oktavianus, P. 2012. Analisis faktor lingkungan untuk penentuan dan zonasi daerah resapan air pada ekosistem kawasan karst di kota Kupang dan sekitarnya. Tesis. Yogyakarta. Pascasarjana UGM

Rahardjo, N.; Purnama, S. dan Sulaswono, B. Pemetaan potensi mataair di Pulau Bali. Jurnal Geografi Vol. 4(2): 71-79 ISSN: 2085-3866. Yogyakarta: Fakultas Geografi UGM

Sweeting, M.M. 1972. Karst Landforms. London: Macmilland www.goapindul.org. Diakses pada tgl 30-5-2016 pukul 20.00 www.jogiatrip.com. Diakses pada tgl 30-5-2016 pukul 20.00 
www.travel.kompas.com.Diakses pada tgl 30-5-2016 pukul 20.00

Makalah ini merupakan bagian dari Buku Seri Bunga Rampai dengan Judul "Hidrologi dan Kepariwisataan Kawasan karst Goa Pindul Kabupaten Gunungkidul” dengan Editor Slamet Suprayogi, Setyawan Purnama, Ahmad Cahyadi, Hendy Fatchurohman. Buku ini diterbitkan oleh Badan Penerbit Fakultas Geografi (BPFG) Universitas Gadjah Mada di Yogyakarta Tahun 2016. Makalah ini termuat dalam Halaman 83-107 